\title{
Technical Assessment of River Training Impact on the Raba River Bed Stability on the Selected Longitudinal Section
}

\author{
Marta Łapuszek $^{1 *}$, Andrzej Wolak ${ }^{1}$ \\ 1 Institute of Water Engineering and Water Management, Cracow University of Technology, ul. Warszawska 24, \\ 31-155 Kraków, Poland \\ * Corresponding author's e-mail: mlapusze@iigw.pl
}

\begin{abstract}
Short assessment and prediction of movement of selected Raba river sections in Southern Poland, using the existing, historical sources is presented in this paper. It was done to the most practicable extent, with regard to the river training structures as groynes and revetments stability structures. The old maps (almost non-existent) and/or aerial photographs of the selected areas and the archival projects of technical Raba river channel regulation were complemented with specific stream power and bed shear stress. In the $8.2 \mathrm{~km}$ long study area, four specific sections were studied in the current paper. The general trends over the last fifty years included artificial narrowing of the active channel width with uniform riverbed longitudinal slope. The current studies lead to the conclusion that the narrowed river channel tend to restoring its previous state. However, throughout each analyzed section, the channel-forming processes are varied, mostly related to restoring the local natural longitudinal slope. In Section-1, the process of sediment deposition was observed and it continues till now. In Section-2, the channel-forming processes were carried out with high intensity with tendency to rebuild its previous braided course. Currently, this tendency is continuing. The third Section seems to be the most stable after the river training works. In Section- 4 the process of high erosion, especially of the left bank, is observed. The results of the analysis lead to the conclusion that more comprehensive investigation is needed of the whole $8.2-\mathrm{km}$ long reach to assess the river state.
\end{abstract}

Keywords: river training, riverbed stability, river restoration.

\section{INTRODUCTION}

Horizontal stability of streams and rivers is one of the most obvious effects of ever-changing morphology of mountain valleys. It can be beneficial for the entire ecosystem (Bravard et al., 1999, May et al., 2009,), or it can be harmful, especially for human development. For centuries, the human tried to rein-in the river corridor migration; however, sometimes their efforts backfired spectacularly (Lisle, 2005, Nelson et al., 2009).

In this paper, assessment and prediction of the movement of selected sections of the Raba river in Southern Poland was attempted, using existing, historical sources, to the most practicable extent, with regard to the structures as groyneses and revetments stability.

This paper uses multi-disciplinary tools to assess the river channel changes. Therefore, the first step was to obtain the information, in the form of old maps (almost non-existent) and/or aerial photographs of the selected areas. This was somewhat successful, as about 200 aerial photographs were collected, albeit in various states of preparation. Some were scanned simply from the raw photographic slides, with almost no correction, some of them were somewhat better prepared ortophoto representations of the quality similar to widely used ortophoto maps (Carbonneau et al., 2004, Legleiter 2013).

Secondly, the archival projects of technical Raba river channel training works were collected and thoroughly analysed. It was done in order to assess the influence on the channel evolution and the groynes stability, taking into account the variability of the hydrologic regime of the analyzed area. (Mosley 1982, Stevens et al., 1975). 


\section{THE STUDY AREA}

Raba River, in southern Poland, is a mountain tributary of Vistula River, which drains $1537 \mathrm{~km}^{2}$ catchment (according to Institute of Meteorology and Water Management). The topography of drainage catchment is highly varied in this region. Raba River is characterized by high erosion and deposition processes, which occur with varied intensity along the river course. The experimental reach (the study area) is located from $86.376 \mathrm{~km}$ to $78.142 \mathrm{~km}$ of Raba River (counting from its mouth). The river is quite braided, with free bars. The width of the active channel can rise up to 180 $\mathrm{m}$ in some parts of the studied river course. During the $20^{\text {th }}$ century, the river in the studied reach was repeatedly straightened and narrowed. In 1967, the most complex river training was carried out. The main river channel was designed as a trapezoid of $30 \mathrm{~m}$ width with both-side limitation of made of groynes and revetments. This engineering activity was the most important factor of high riverbed evolution. The newly formed narrow river channel did not survive long, the most of the structures as groynes and revetments were destroyed. Hence, subsequent regulations were carried out for the next decades with the river channel was formed as $50 \mathrm{~m}$ width.

The concern of the paper is the horizontal and vertical stability assessment in four selected sections of the studied area where the changes of river channel are the most visible: Section-1 - km: 79.510-80.196; Section-2-km: 81.144-81.908;
Section-3 - km: $83.056-84.308$; Section-4 km: $84.491-85.872$ (Fig. 1).

\section{MATERIALS AND METHODS}

Since 1963, aerial photographs have been taken periodically by the Main Office of Geodesy and Cartography (in Polish: GUGIK) for the Raba river catchment. In the current research, the aerial photographs of: 1963, 1980, 1997, 2003, 2009, 2012, 2015 have been used (50 separate photos). It is important that these photographs were made during the low flow conditions, with clear opportunity to assess the variability of the location of the riverbed in the plan (Table 1). It was then possible to obtain much better resolution using the historical aerial photos obtained from GUGiK, than using the freely available ones (Google for example).

The details of technical training projects carried out on selected sections of the Raba river were obtained from Wody Polskie (RZGW Kraków), for the years: 1967, 1973, 1975, 1982, 1987. On the basis of the archival projects, it was possible to analyze the vertical and horizontal changes of the river channel.

It was then possible to assess the variability of the active channel width (treated as a width not covered by vegetation) using those aerial photographs and the maps and cross-sections of the archival technical projects. The raster resolutions of the aerial photographs used to the current studies
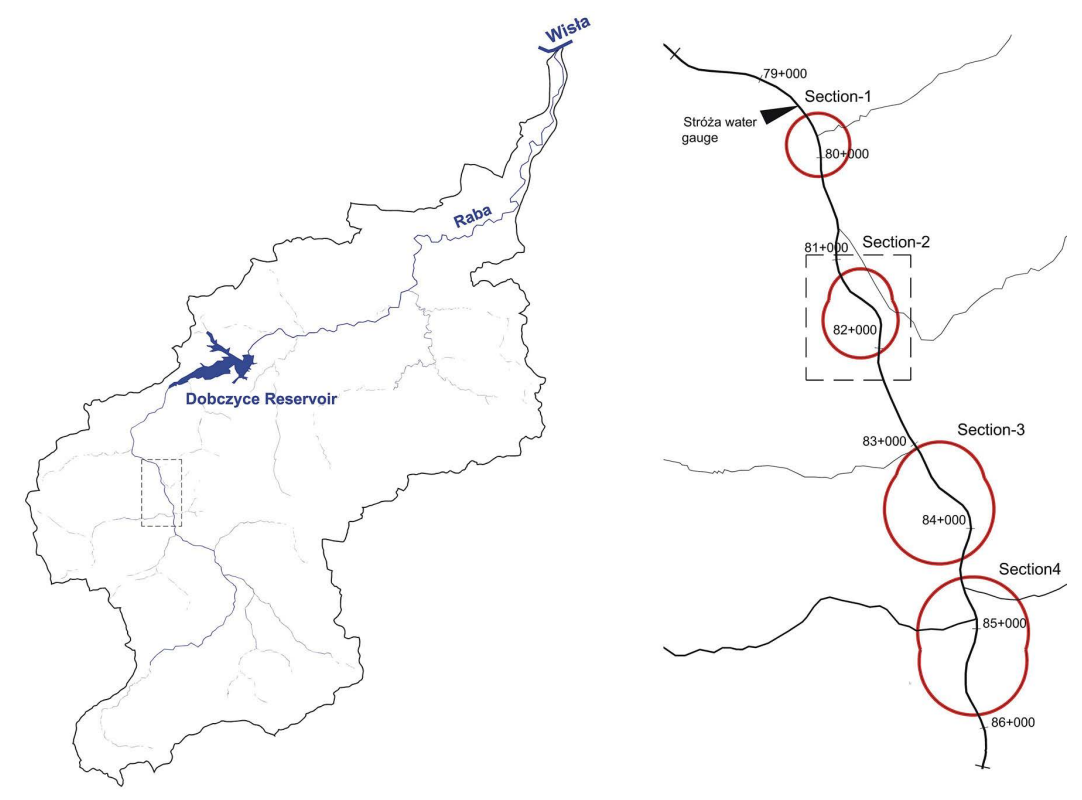

Figure 1. Raba river catchment and the study area location 
Table 1. Discharges that occurred while taking aerial photographs on the Raba river, whereas the characteristic discharges at Stróża gauging station (the catchment area: $644 \mathrm{~km}^{2}$ ) are as follows: $\mathrm{Q}_{\text {mean annual }}=9.24 \mathrm{~m}^{3} / \mathrm{s}$, $\mathrm{Q}_{\text {min. }}=0.70 \mathrm{~m}^{3} / \mathrm{s}, \mathrm{Q}_{50 \%}=164 \mathrm{~m}^{3} / \mathrm{s}, \mathrm{Q}_{10 \%}=521 \mathrm{~m}^{3} / \mathrm{s}, \mathrm{Q}_{5 \%}=676 \mathrm{~m}^{3} / \mathrm{s}, \mathrm{Q}_{1 \%}=1040 \mathrm{~m}^{3} / \mathrm{s}$ (according to Institute of Meteorology and Water Management)

\begin{tabular}{|c|c|c|c|c|c|c|c|c|c|c|c|c|}
\hline The date & $\begin{array}{c}18.09 . \\
1963\end{array}$ & $\begin{array}{c}22.09 . \\
1963\end{array}$ & $\begin{array}{c}6.05 . \\
1980\end{array}$ & $\begin{array}{c}15.05 . \\
1980\end{array}$ & $\begin{array}{c}16.05 . \\
1980\end{array}$ & $\begin{array}{c}15.09 . \\
1997\end{array}$ & $\begin{array}{c}15.04 . \\
2003\end{array}$ & $\begin{array}{c}16.04 . \\
2009\end{array}$ & $\begin{array}{c}18.07 . \\
2009\end{array}$ & $\begin{array}{c}10.08 . \\
2009\end{array}$ & $\begin{array}{c}29.07 . \\
2012\end{array}$ & $\begin{array}{c}13.06 . \\
2015\end{array}$ \\
\hline $\begin{array}{c}\text { Flow in } \\
\text { river } \\
{\left[\mathrm{m}^{3} \cdot \mathrm{s}^{-1}\right]}\end{array}$ & 2.3 & 2.62 & 9.04 & 6.48 & 5.84 & 5.64 & 9.6 & 10 & 2.98 & 2.13 & 5.54 & 2.5 \\
\hline
\end{tabular}

are relatively good. However, the effects of some image deformations cannot be completely rectified, especially of the areas located at the considerable distance from the central part of photography. The problem concerns especially the maps of 1963, 1980. Moreover, river bank digitization is a great challenge in the areas covered with dense vegetation.

The width of the channel estimated from the technical projects (Raba river training projects: $1967,1973,1976,1982,1987)$ is characterized by an error of $7-10 \%$. This is due to the difficulties in line estimation between the bottom and the riparian zone: in some cases, the outlines of the channel bottom pointed out on the plan do not correspond to the cross-section. The current state of channel active width was possible to estimate based on the field observation. There were some areas where the extent of sediment cover was made under the assumption that the active width is the area over which bed material is mobile at any particular time and morphological change can be observed (Ashmore, 2001; Bertoldi et al., 2009b, Lane et al., 1994;).

The river bottom vertical variability was determined by comparing the lowest cross-sectional ordinates pointed out in the technical projects.

In order to examine the hydrodynamic condition of the river channel in the years 1967-2015, the daily discharges registered in Stróża gauging station ( $80.6 \mathrm{~km}$ of the Raba river) were analyzed. In the particular time intervals, the sequences of channel-forming flows were determined on the basis of the MPM formula (1948), where the left side stands for the shear stress and the right side for the stream power:

$\gamma \frac{Q_{s}}{Q}\left(\frac{k_{s}}{k_{r}}\right)^{\frac{3}{2}} h J=0,047 \cdot \gamma_{s}^{\prime} d+0,25 \cdot\left(\frac{\gamma}{g}\right)^{\frac{1}{3}} q_{s}^{\frac{2}{3}}$

where: $q_{s}-$ sediment flow $\left[\mathrm{N} \cdot \mathrm{s}^{-1} \mathrm{~m}^{-1}\right]$;

$k_{s^{\prime}}, k_{r}$ - velocity coefficient in Manning Strickler formulae [-];

$h$ - water depth; $d$ - sediment diameter;
$J$-slope of the energy line [-],

$Q$ - water discharge $\left[\mathrm{m}^{3} / \mathrm{s}\right]$,

$Q_{s}$ - water discharge due to beginning of sediment movement $\left[\mathrm{m}^{3} / \mathrm{s}\right], \mathrm{g}_{\mathrm{r}}-$ specific weight of sediment, $g_{r}=2650\left[\mathrm{~kg} / \mathrm{m}^{3}\right]$, $\mathrm{g}-$ acceleration due to gravity $\left[\mathrm{m} / \mathrm{s}^{2}\right]$.

Specific stream power $\omega$, was determined with the following relationship: (Bagnold, 1966, Parker et al., 2011):

$$
\omega=\rho g Q S / W
$$

where: $Q\left(\mathrm{~m}^{3} \cdot \mathrm{s}^{-1}\right)$ - bankfull discharge,

$S$ - energy slope

$W$ - channel width [m].

\section{RESULTS AND PROGNOSIS}

Spatially, the study area was divided into four particular sections: numbered from 1 to 4 . The proposed allocation results in the "belt" adopted as $92 \%$ of river migration in plan observed throughout the whole studied section.

Considering time intervals, the research area was divided into:

- four time intervals: 1963-1980, 1980-2012, 2012-2015, 2015-2017, related to the availability of photogrammetric materials;

- periods related to the river training activities in the following areas: 1967-1976, 1967-1976-1987, 1967-1982, 1967 until now, respectively.

\section{Vertical stability analysis}

The changes were determined on the basis on the technical projects executed on the studied Raba river sections (Raba river training projects). Taking into account the field measurements made, due to projects preparation in 1967 and 1976, the vertical variability of river channel in Section-1 was assessed. In 1967, before the project execution, the sediment accumulation processes (in the 
upper part) and the local bottom lowering $(1.0 \mathrm{~m})$ close to $\mathrm{km} 79.800$ were observed. As a result of the technical river training in 1967, the Raba riverbed reach in bars and landforms was narrowed to $30.0 \mathrm{~m}$ and the longitudinal slope of the bottom was standardized to 0.004 (elevation divided by distance). In 1976, another technical training works on this section were executed with the same slope designed as in 1967 and the channel width of $50 \mathrm{~m}$.

A) 1963

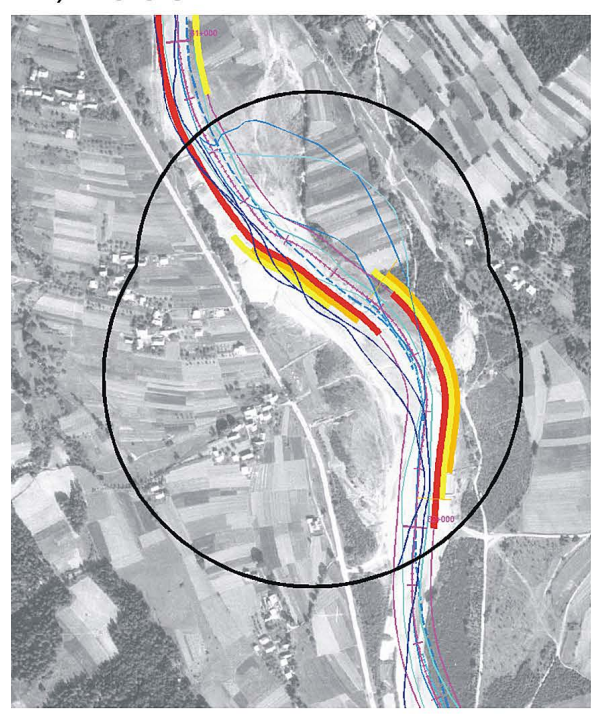

C) 2012
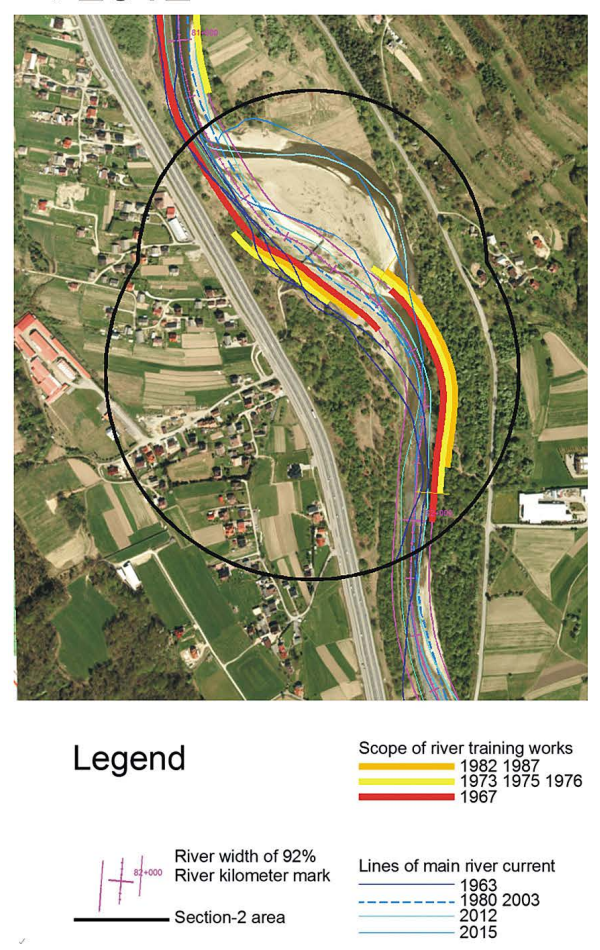

As shown by the measurements of the channel on this section, in 1967, after training works until 1976 there were very intensive bottom aggradations, on average for about $1.0 \mathrm{~m}$ (Table 2). In Tables (Tables: 2-5) the vertical stability analysis in four sections was presented. It includes the initial bottom level and the active channel width before the first river training and the increase or decrease of these values in the studied time intervals connected with the periods of the

\section{B) 1980}

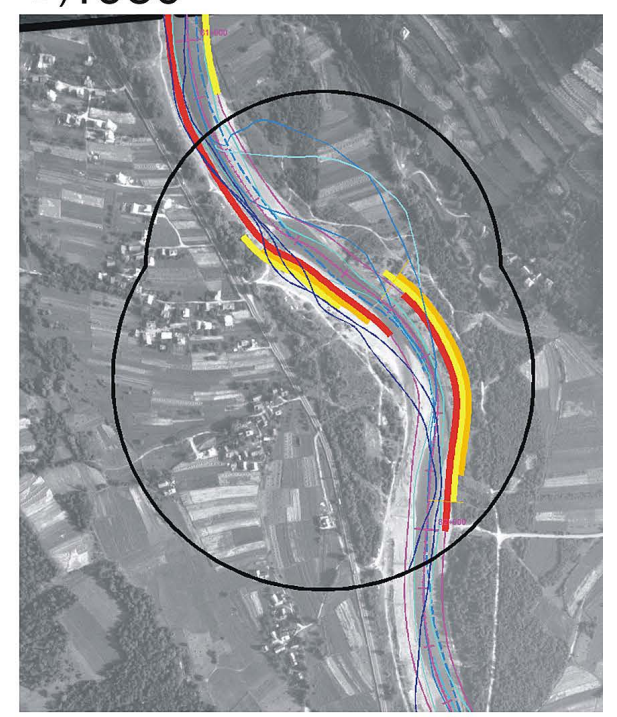

D) 2015
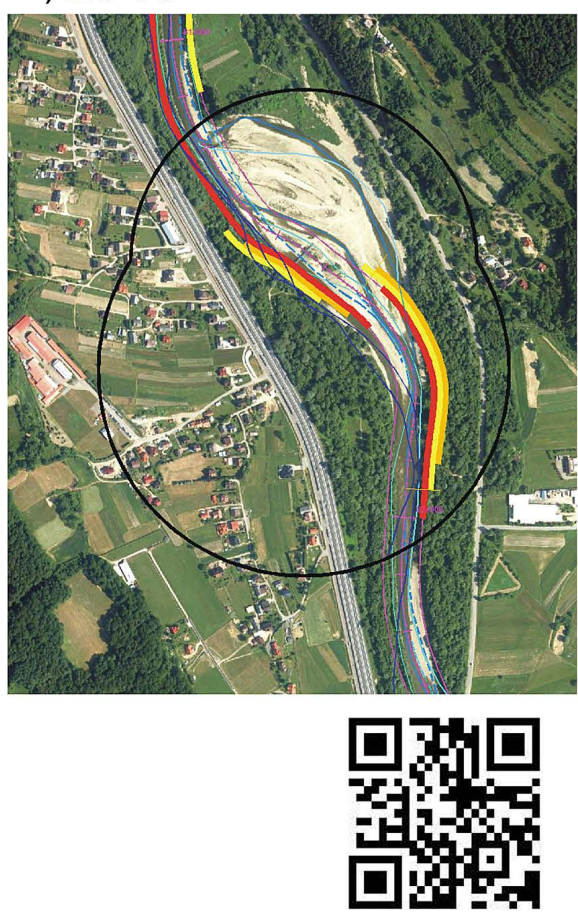

Figure 2. Section-2 (km: 81.144 - 81.908): Raba river channel evolution in years: a) 1963,

b) 1980 , c) 2012 , d) 2015 observed on the aerial photography with pointed out training works during observed time intervals. Position: $49^{\circ} 45^{\prime} 58.0^{\prime \prime} \mathrm{N} 19^{\circ} 57^{‘} 56.7^{\prime ‘} \mathrm{E}(49.766112,19.965758)$ 
river training works. Due to the multiplicity of analyzed cross-sections in a given section (one of the four), the tables present the results only for selected cross-sections.

In Section-2 trained technical channel in 1967 tends to have the bottom aggradations with the observed sediment layer of thickness between 1.0-1.8 m (Table 3, Fig. 3).

After river training carried out in 1973 (the channel width: $\mathrm{B}=50 \mathrm{~m}$, slope: $\mathrm{J}=0.004$ ) erosion and accumulation of sediment with intensity ranged from $-0.6 \mathrm{~m}$ (erosion) to $+0.4 \mathrm{~m}$ (deposition) was observed till the year 1987 (Table 3. Fig. 3).

In Section-3 after the technical works of 1967 , the vertical shape of the channel was clearly transformed. While comparing the bottom level to the bottom measured in 1982, the process of riverbed erosion was observed along the whole Section-3 (Table 4).

Currently, in Section-4 there are no geometry data of cross-sections of any period of time except of 1967 year. Therefore, the vertical variability can not be assessed at present. This will only be possible after field measurements (Table 5).

\section{Horizontal analysis and prognosis}

The morphological active width can be defined as the lateral extend of bed material displacement in time (Peirce et al., 2018). However, the bedload transport in gravel-bed rivers has substantial variability and is often limited to the threads of transport that are often narrower than the riverbed itself (Gomez 1991). The recent studies showed that in a few wetted channels of a braided river, in one or two channels only the bedload transport occurs (Bertoldi et al., 2009, Egozi et al., 2009). Defining and measuring channel active width is extensively presented in the literature (Brasington et al., 2000, 2003, Gomez 1991, Ferguson et al., 1992, Lane et al., 1994, Rumsby et al., 2008). In the current study, channel active width is assessed as the area between the boundary lines of riparian vegetation on both banks of the river, including bars not covered with vegetation and the area over which bed material is mobile. The active width variability analysis in four selected sections of the Raba river was possible since 1963, when the area was first covered by aerial photography.
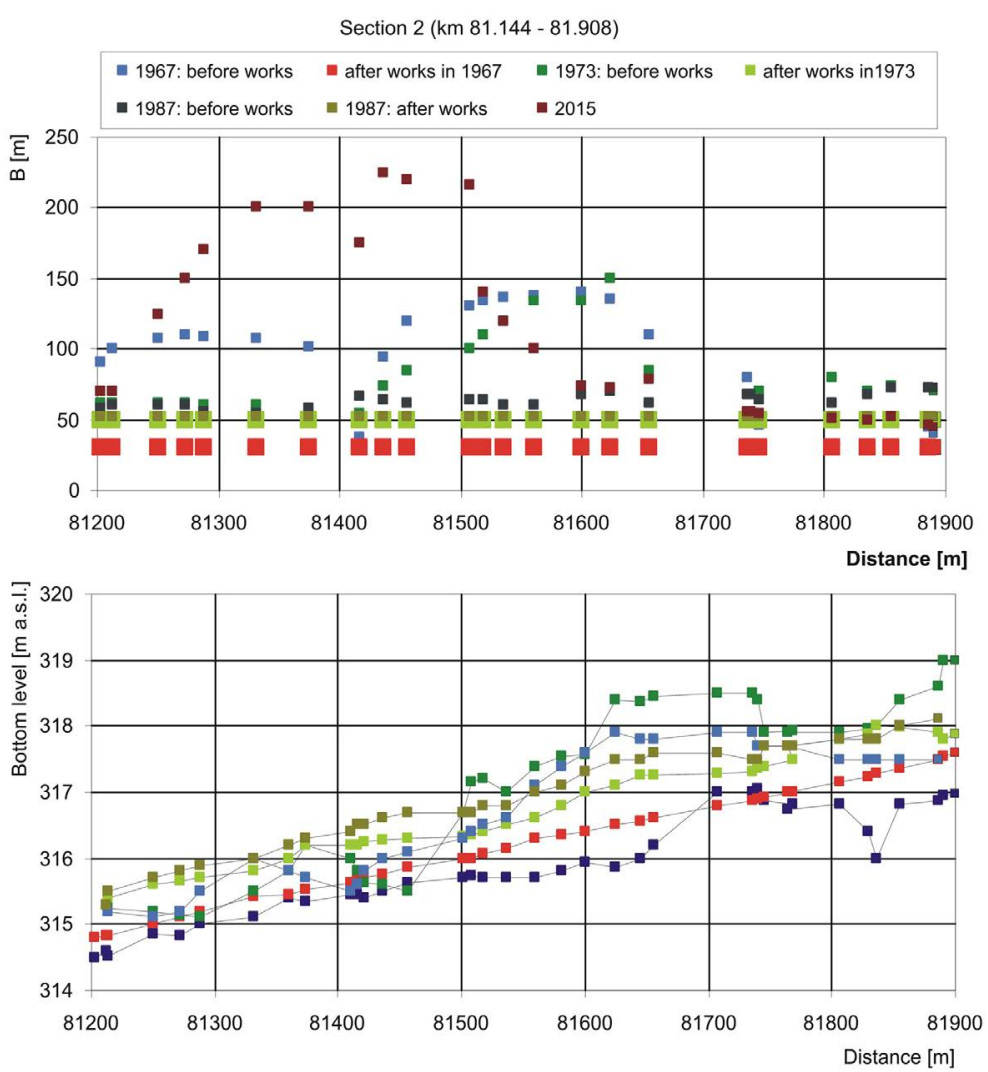

Figure 3. Section-2 (km: $81.144-81.908)$ : the active channel width and bottom level variability in analyzed time intervals (due to the technical projects) 
Table 2. Raba river channel changes in the years 1967-2015 in Section-1

\begin{tabular}{|c|c|c|c|c|c|c|c|c|c|c|}
\hline \multirow{3}{*}{$\begin{array}{c}\text { Section-1 } \\
\text { Cross- } \\
\text { section } \\
\text { [km from } \\
\text { mouth] }\end{array}$} & \multirow{2}{*}{\multicolumn{2}{|c|}{ Years: before - 1967}} & \multirow{2}{*}{\multicolumn{2}{|c|}{$\begin{array}{l}\text { River training works: } \\
\qquad 1967\end{array}$}} & \multirow{2}{*}{\multicolumn{2}{|c|}{$\begin{array}{c}\text { Increase/decrease } \\
\text { compared to river } \\
\text { training project data } \\
\text { Years: } 1967-1976\end{array}$}} & \multirow{2}{*}{\multicolumn{2}{|c|}{$\begin{array}{l}\text { River training works: } \\
1976\end{array}$}} & \multirow{2}{*}{\multicolumn{2}{|c|}{$\begin{array}{l}\text { Increase/decrease } \\
\text { compared to river } \\
\text { training project data } \\
\text { Years: } 1976-2015\end{array}$}} \\
\hline & & & & & & & & & & \\
\hline & $\begin{array}{c}\text { Bottom } \\
\text { level } \\
\text { [m a.s.l.] }\end{array}$ & $\begin{array}{l}\text { Channel } \\
\text { width } \\
\text { [m] }\end{array}$ & $\begin{array}{c}\text { Bottom } \\
\text { level } \\
\text { [m a.s.l.] }\end{array}$ & $\begin{array}{l}\text { Channel } \\
\text { width } \\
\text { [m] }\end{array}$ & $\begin{array}{c}\text { Bottom } \\
\text { level } \\
\Delta \mathrm{h}[\mathrm{m}]\end{array}$ & $\begin{array}{c}\text { Channel } \\
\text { width } \\
\Delta \mathrm{b}[\mathrm{m}]\end{array}$ & $\begin{array}{c}\text { Bottom } \\
\text { level } \\
\text { [m a.s.l.] }\end{array}$ & $\begin{array}{l}\text { Channel } \\
\text { width } \\
\text { [m] }\end{array}$ & $\begin{array}{c}\text { Bottom } \\
\text { level } \\
\Delta \mathrm{h}[\mathrm{m}]\end{array}$ & $\begin{array}{c}\text { Channel } \\
\text { width } \\
\Delta b[\mathrm{~m}]\end{array}$ \\
\hline 80.196 & 311.7 & 60 & 310.8 & 30 & +0.8 & +42 & 311.9 & 50 & & +5 \\
\hline 80.049 & 311.6 & 110 & 310.3 & 30 & +1.0 & +48 & 311.4 & 50 & & +3 \\
\hline 79.834 & 316.2 & 70 & 309.4 & 30 & +1.2 & +39 & 310.7 & 50 & No data & +50 \\
\hline 79.790 & 308.3 & 60 & 309.3 & 30 & +1.1 & +44 & 310.5 & 50 & & +80 \\
\hline 79.696 & 309.0 & 82 & 308.7 & 30 & +1.1 & +46 & 310.3 & 50 & & +11 \\
\hline 79.510 & 308.0 & 96 & 308.1 & 30 & +0.6 & +50 & 309.3 & 50 & & +0 \\
\hline
\end{tabular}

Table 3. Raba river channel changes in the years 1967-2015 in Section-2

\begin{tabular}{|c|c|c|c|c|c|c|c|c|c|c|c|c|}
\hline \multirow{3}{*}{$\begin{array}{c}\text { Section-2 } \\
\text { Cross- } \\
\text { section } \\
\text { [km from } \\
\text { mouth] }\end{array}$} & \multirow{2}{*}{\multicolumn{2}{|c|}{$\begin{array}{c}\text { Years: } \\
\text { before }-1967\end{array}$}} & \multirow{2}{*}{\multicolumn{2}{|c|}{$\begin{array}{l}\text { River training } \\
\text { works: } 1967\end{array}$}} & \multirow{2}{*}{\multicolumn{2}{|c|}{$\begin{array}{c}\text { Increase/decrease } \\
\text { compared to river } \\
\text { training project data } \\
\text { Years: } 1967-1973\end{array}$}} & \multirow{2}{*}{\multicolumn{2}{|c|}{$\begin{array}{l}\text { River training } \\
\text { works: } 1973\end{array}$}} & \multicolumn{4}{|c|}{$\begin{array}{c}\text { Increase/decrease } \\
\text { compared to river training project data }\end{array}$} \\
\hline & & & & & & & & & \multicolumn{2}{|c|}{ Years: 1973-1987 } & \multicolumn{2}{|c|}{ 1987-2015 } \\
\hline & $\begin{array}{l}\text { Bottom } \\
\text { level } \\
{[\mathrm{m}} \\
\text { a.s.l. }]\end{array}$ & $\begin{array}{l}\text { Channel } \\
\text { width } \\
\text { [m] }\end{array}$ & $\begin{array}{l}\text { Bottom } \\
\text { level } \\
{[\mathrm{m}} \\
\text { a.s.I. }]\end{array}$ & $\begin{array}{l}\text { Channel } \\
\text { width } \\
\text { [m] }\end{array}$ & $\begin{array}{l}\text { Bottom } \\
\text { level } \\
\Delta \mathrm{h}[\mathrm{m}]\end{array}$ & $\begin{array}{l}\text { Channel } \\
\text { width } \\
\Delta \mathrm{b}[\mathrm{m}]\end{array}$ & $\begin{array}{l}\text { Bottom } \\
\text { level } \\
{[\mathrm{m}} \\
\text { a.s.I. }]\end{array}$ & $\begin{array}{l}\text { Channel } \\
\text { width } \\
\text { [m] }\end{array}$ & $\begin{array}{l}\text { Bottom } \\
\text { level } \\
\Delta \mathrm{h}[\mathrm{m}]\end{array}$ & $\begin{array}{l}\text { Channel } \\
\text { width } \\
\Delta \mathrm{b}[\mathrm{m}]\end{array}$ & $\begin{array}{l}\text { Bottom } \\
\text { level } \\
\Delta \mathrm{h}[\mathrm{m}]\end{array}$ & $\begin{array}{c}\text { Channel } \\
\text { width } \\
\Delta \mathrm{b}[\mathrm{m}]\end{array}$ \\
\hline 81.855 & 316.8 & 49 & 317.3 & 30 & +1.1 & +44 & 317.9 & 50 & -0.4 & +12 & & +2 \\
\hline 81.806 & 316.8 & 47 & 317.1 & 30 & +0.7 & +50 & 317.8 & 50 & -0.3 & +12 & & +1 \\
\hline 81.656 & 316.2 & 110 & 316.6 & 30 & +1.8 & +54 & 317.2 & 50 & +0.6 & +12 & $\begin{array}{l}\text { No } \\
\text { data }\end{array}$ & +39 \\
\hline 81.508 & 315.7 & 90 & 316.0 & 30 & +1.4 & +70 & 316.3 & 50 & +0.0 & +14 & & +166 \\
\hline 81.436 & 315.5 & 94 & 315.7 & 30 & 0 & +44 & 316.3 & 50 & -0.2 & +14 & & +175 \\
\hline 81.272 & 314.8 & 110 & 315.1 & 30 & 0 & +32 & 315.6 & 50 & -0.4 & +10 & & +99 \\
\hline
\end{tabular}

Table 4. Raba river channel changes in the years 1967-2015 in Section-3

\begin{tabular}{|c|c|c|c|c|c|c|c|c|c|c|}
\hline \multirow{3}{*}{$\begin{array}{c}\text { Section-3 } \\
\text { Cross- } \\
\text { section } \\
\text { [km from } \\
\text { mouth] }\end{array}$} & \multirow{2}{*}{\multicolumn{2}{|c|}{ Years: before - 1967}} & \multirow{2}{*}{\multicolumn{2}{|c|}{$\begin{array}{l}\text { River training works: } \\
\qquad 1967\end{array}$}} & \multirow{2}{*}{\multicolumn{2}{|c|}{$\begin{array}{l}\text { Increase/decrease } \\
\text { compared to river } \\
\text { training project data } \\
\text { Years: } 1967-1982\end{array}$}} & \multirow{2}{*}{\multicolumn{2}{|c|}{$\begin{array}{l}\text { River training works: } \\
\qquad 1982\end{array}$}} & \multirow{2}{*}{\multicolumn{2}{|c|}{$\begin{array}{l}\text { Increase/decrease } \\
\text { compared to river } \\
\text { training project data } \\
\text { Years: } 1982-2015\end{array}$}} \\
\hline & & & & & & & & & & \\
\hline & $\begin{array}{c}\text { Bottom } \\
\text { level } \\
\text { [m a.s.I.] }\end{array}$ & $\begin{array}{c}\text { Channel } \\
\text { width } \\
{[\mathrm{m}]}\end{array}$ & $\begin{array}{c}\text { Bottom } \\
\text { level } \\
\text { [m a.s.l.] }\end{array}$ & $\begin{array}{c}\text { Channel } \\
\text { width } \\
\text { [m] }\end{array}$ & $\begin{array}{c}\text { Bottom } \\
\text { level } \\
\Delta \mathrm{h}[\mathrm{m}]\end{array}$ & $\begin{array}{c}\text { Channel } \\
\text { width } \\
\Delta \mathrm{b}[\mathrm{m}]\end{array}$ & $\begin{array}{c}\text { Bottom } \\
\text { level } \\
\text { [m a.s.I.] }\end{array}$ & $\begin{array}{c}\text { Channel } \\
\text { width } \\
{[\mathrm{m}]}\end{array}$ & $\begin{array}{c}\text { Bottom } \\
\text { level } \\
\Delta \mathrm{h}[\mathrm{m}]\end{array}$ & $\begin{array}{c}\text { Channel } \\
\text { width } \\
\Delta \mathrm{b}[\mathrm{m}]\end{array}$ \\
\hline 84.308 & 327.7 & 90 & 327.3 & 30 & No data & No data & No data & 50 & & +16 \\
\hline 84.080 & 327.0 & 220 & 326.2 & 30 & -0.7 & +46 & 325.6 & 50 & & +30 \\
\hline 83.850 & 326.1 & 160 & 325.15 & 30 & -0.7 & +22 & 324.7 & 50 & No data & +15 \\
\hline 83.686 & 324.5 & 110 & 324.6 & 30 & -0.5 & +22 & 323.2 & 50 & & +2 \\
\hline 83.509 & 324.6 & 70 & 323.8 & 30 & -0.4 & +30 & 323.4 & 50 & & -12 \\
\hline 83.411 & 323.2 & 84 & 323.5 & 30 & -0.5 & +38 & 323.0 & 50 & & +5 \\
\hline
\end{tabular}

In the years 1963-67, according to the aerial photography and technical project, the active channel width of Section-1 was estimated to be very varied, and it ranged on average from 60 to $110 \mathrm{~m}$ (Table 2), with the average longitudinal slope: $0.008-0.004$ and for discharge $\mathrm{Q}_{\text {min annual }}: \omega=14.5-28 \mathrm{~W} / \mathrm{m}^{2}$ and $\tau=12-14 \mathrm{~N} / \mathrm{m}^{2}$.
In the years of 1963-1967, the channel-forming discharge was calculated as $Q_{67 \%}=102 \mathrm{~m}^{3} / \mathrm{s}$., together and with higher values it lasted only for 5 days. In this time period, the maximum observed flow was $\mathrm{Q}_{\max }=257 \mathrm{~m}^{3} / \mathrm{s}$. Hence, the channel was shaped by the hydrological and hydraulic conditions only. 
Table 5. Raba river channel changes in the years 1967-2015 in Section-4

\begin{tabular}{|c|c|c|c|c|c|c|}
\hline \multirow[t]{2}{*}{ Section-4 } & \multirow{2}{*}{\multicolumn{2}{|c|}{ Years: before - 1967}} & \multirow{2}{*}{\multicolumn{2}{|c|}{ River training works: 1967}} & \multirow{2}{*}{\multicolumn{2}{|c|}{$\begin{array}{c}\text { Increase/decrease } \\
\text { compared to river training project } \\
\text { data } \\
\text { Years: } 1967-2015\end{array}$}} \\
\hline & & & & & & \\
\hline $\begin{array}{l}\text { Cross-section } \\
{[\mathrm{km} \text { from mouth }]}\end{array}$ & $\begin{array}{c}\text { Bottom level } \\
\text { [m a.s.l.] }\end{array}$ & $\begin{array}{c}\text { Channel width } \\
{[\mathrm{m}]}\end{array}$ & $\begin{array}{l}\text { Bottom level } \\
\text { [m a.s.l.] }\end{array}$ & $\begin{array}{l}\text { Channel width } \\
{[\mathrm{m}]}\end{array}$ & $\begin{array}{c}\text { Bottom level } \\
\Delta \mathrm{h}[\mathrm{m}]\end{array}$ & $\begin{array}{l}\text { Channel width } \\
\qquad \Delta \mathrm{b}[\mathrm{m}]\end{array}$ \\
\hline 85.176 & 331.8 & 220 & 331.4 & 30 & No data & +165 \\
\hline 84.802 & 329.7 & 160 & 329.8 & 30 & & +41 \\
\hline 84.491 & 328.4 & 100 & 328.2 & 30 & & +19 \\
\hline
\end{tabular}

In 1967, due the technical river training the braided channel with bars was narrowed to $30.0 \mathrm{~m}$ with slope of 0.004 . The newly formed channel was shaped on both sides by a system of groynes (Project 1967). Thus, the active width was artificially narrowed up to $50 \%$, and locally even up to more than $80 \%$. Under the new conditions, after the works, the hydraulic parameters were as follows: for discharge $\mathrm{Q}_{\min \text { annual }}: \omega=12 \mathrm{~W} / \mathrm{m}^{2}$, and for discharge initiating the sediment movement $\mathrm{Q}=58 \mathrm{~m}^{3} / \mathrm{s}: \omega=32 \mathrm{~W} / \mathrm{m}^{2}$ and $\tau=38 \mathrm{~N} / \mathrm{m}^{2}$.

In the following years 1967-1976: the channel-forming discharge was calculated as $\mathrm{Q}_{67 \%}=58 \mathrm{~m}^{3} / \mathrm{s}$ and with higher values, it lasted for 38 days. The maximum observed flow was $\mathrm{Q}_{\max }=475 \mathrm{~m}^{3} / \mathrm{s}$ this time period. The field measurements showed that 9 years later the active width was restored by the river itself to the pre1967 training works (Table 2).

In 1976, the technical training in Section-1 was made, shaping the channel with $50.0 \mathrm{~m}$ of width (Project 1967). The channel-forming discharge for new conditions was calculated as $\mathrm{Q}=74 \mathrm{~m}^{3} / \mathrm{s}$, and the hydraulic conditions were as follows: $\omega=38 \mathrm{~W} / \mathrm{m}^{2}$ and $\tau=33 \mathrm{~N} / \mathrm{m}^{2}$. In the years 1976-1980, the above-mentioned hydraulic parameters did not change.

In the next years, the evaluation of the river channel in the horizontal system analysis was possible on the basis of aerial photographs. An aerial photo taken in 1980 indicates that the riverbed in the plan was stable, slight right bank erosion and slight bars deposition were initiated. In the years 1980-2012, the channel-forming discharge $\mathrm{Q}_{\text {ch-form. }}=74 \mathrm{~m}^{3} / \mathrm{s}$ with higher lasted for 124 days and the maximum observed was: $Q_{\max }=385 \mathrm{~m}^{3} / \mathrm{s}$. In 2012, the aerial photo indicates a rapid deepening of the right bank erosion just behind the groyens constructed in 1967. The left bank was eroded as well. Meantime, the bars changed into a large island in the middle. In years: 2012-2015: the channel-forming discharge $Q_{\text {ch-form. }}=76 \mathrm{~m}^{3} / \mathrm{s}$ with higher lasted for 124 days ad the maximum observed was: $Q_{\max }=361 \mathrm{~m}^{3} / \mathrm{s}$. In 2015 , the process of erosion is continuing on the right bank.

The current active width assessment shows the process which formed the new active channel with width of 120-130 m, as it was before the first technical training works. The space for the active channel was created by the river itself (Table 2).

Prognosis: According to vertical stability analysis, the riverbed tends to accumulate sediment in the studied Section-1. The continuing process of sediment deposition in the river channel will cause the longitudinal slope and decreasing of unit stream power. The balance of sediment movement will be disturbed in favor of intensive deposition. Despite the right bank protection, erosion will continue and the local Pcim-Stróża road and the buildings of Wierciakowo Village will be threatened. The exact determination of these processess requires further model calculations.

In the years 1963-67, according to the aerial photography and technical project, the active width of Section-2 was estimated. Before river training, the width of the active channel was varied and ranged from $50 \mathrm{~m}$ to $140 \mathrm{~m}$, it was braided with many bars. Up to a year 1967, the hydraulic parameters of the channel for discharge $Q_{\text {min annual }}$ were as follows: $\omega=12-22 \mathrm{~W} / \mathrm{m}^{2}$, $\tau=10-15 \mathrm{~N} / \mathrm{m}^{2}$. The channel-forming discharge was estimated as $\mathrm{Q}_{67 \%}=102 \mathrm{~m}^{3} / \mathrm{s}$ and it lasted with higher for 5 days only. The maximum observed discharge was $Q_{\max }=257 \mathrm{~m}^{3} / \mathrm{s}$. In 1967, due the technical training, the new narrow, prismatic channel was formed with the same parameters as in the case of Section-1. In the years 1967-1973 after river training channel-forming discharge was estimated as $Q_{\text {ch-form. }}=58 \mathrm{~m}^{3} / \mathrm{s}$ and it lasted with higher for 26 days and the maximum observed discharge was $Q_{\max }=475 \mathrm{~m}^{3} / \mathrm{s}$. In 1973, the field measurements showed that throughout the Section-2 the river has not restored the former active channel itself. However, the channel was 
widened for about 10-14 m (Table 3). It means that despite the training works the river channel aims at restoring its former course. The groyneses and revetments could not manage to maintain a 30-meter wide channel. In 1973, the technical training in Section-2 was made again, shaping the width of the channel with $50.0 \mathrm{~m}$ with groyneses and revetments limiting the lateral channel movement (Project 1973). For new condition $\mathrm{Q}_{\text {ch-form. }}=72 \mathrm{~m} / \mathrm{s}$ the parameters of the channel were: $\omega=38 \mathrm{~W} / \mathrm{m}^{2}, \tau=34 \mathrm{~N} / \mathrm{m}^{2}$. The maximum observed discharge was $\mathrm{Q}_{\max }=475 \mathrm{~m}^{3} / \mathrm{s}$.

The aerial photo taken in 1980 shows that the channel was not stable, the left bank was eroded. After left bank protecion, the process of right bank erosion was initiated. In 1987, the training works in Section-2 were carried out again shaping the width of the channel with $50.0 \mathrm{~m}$ with groyneses and revetments limiting the lateral channel movement (Project 1987). The measurement of the channel width after 14 years showed that the river partially returned to its active channel width as it was before the works (Fig.3, Table 3). In the years 1980-1987 the channel-forming discharge was $\mathrm{Q}_{\text {ch-form. }}=72 \mathrm{~m}^{3} / \mathrm{s}$ and it lasted with higher for 47 days, and the maximum observed discharge was $\mathrm{Q}_{\max }=385 \mathrm{~m}^{3} / \mathrm{s}$.

Currently, in Section-2, after almost 30 years, where the first training works have been done, the active channel with bars and bedforms was 100-140 m wide (Fig.2, 3), the channel has then rebuilt its previous state creating new bedforms. In the years 1987-2012, channel-forming discharge was $Q_{\text {ch-form. }}=72 \mathrm{~m}^{3} / \mathrm{s}$ and it lasted with higher for 152 days.

On the basis of the aerial photo taken in 2012, the extreme erosion process of the right bank was noticed. A newly-formed wide river channel appeared there as well. The river was divided into two different courses, with the appearance of a large island (about 4 ha) between the two. Left bank erosion seems to have been effectively stopped. In the years, 2012-2015 channel-forming discharge was $Q_{\text {ch-form. }}=76 \mathrm{~m}^{3} / \mathrm{s}$, and lasted with higher flows for 6 days only. The maximum observed discharge was $Q_{\max }=361 \mathrm{~m}^{3} / \mathrm{s}$. It is well seen in the aerial photo taken in 2012 that the island which has formed between two channels is divided by many small channels of various sizes. The river is restoring its brided pattern (Fig.2).

Prognosis: According to the vertical stability analysis, the riverbed in this area shows alternately intense sedimentation and erosion processess. as long as those processes continue, there is a risk even for the local road on the length of about 700 meters. Field observations indicate intensive sediment movement. However, precise determination of the stream power values and bottom stresses requires modeling calculations, taking into account the current geometry of the Raba river channel on this section.

The aerial photo shows that in years 1963-1967 Section-3 was characterized by braided channel with bed-forms and bars, and with bed activity ranged to $200 \mathrm{~m}$ or more.

Before river training works, the hydraulic parameters of the channel were for $\mathrm{Q}_{\min }: \omega=12-22 \mathrm{~W} / \mathrm{m}^{2}, \tau=10-15 \mathrm{~N} / \mathrm{m}^{2}$. The channel-forming discharge was estimated as $\mathrm{Q}_{67 \%}=102 \mathrm{~m}^{3} / \mathrm{s}$ and it lasted with higher for 5 days only. The river training carried out in 1967 transformed the braided channel into $30 \mathrm{~m}$ width prismatic channel, both-sides limited by groyneses and revetments. In the following years, i.e. 1967-1980, the channel-forming discharge was estimated as $\mathrm{Q}_{\text {ch-form. }}=58 \mathrm{~m}^{3} / \mathrm{s}$ and it lasted with higher flows for 52 days.

In the aerial photo taken in 1980 it can be seen that the river channel is stable in Section-3. In the years 1980-1982, the channel-forming discharge was calculated as $Q_{\text {ch- form. }}=72 \mathrm{~m}^{3} / \mathrm{s}$ and it lasted with higher flows for 11 days only. The maximum observed discharge was $Q_{\max }=173 \mathrm{~m}^{3} / \mathrm{s}$.

The field measurements carried out in 1982 show that in the whole Section-3, the bedload active channel widened itself of about 20-45 m (Table 4). After river training executed in 1982 with the new channel width of $50 \mathrm{~m}$ (for $\mathrm{Q}_{\text {ch-form. }}=72 \mathrm{~m}^{3} / \mathrm{s}: \omega=38 \mathrm{~W} / \mathrm{m}^{2}$ and $\tau=34 \mathrm{~N} / \mathrm{m}^{2}$ ) partly limited by groyneses and revetments (Project 1982). The aerial pictures taken in the following years suggest that the channel tended to widen gradually till now. In the years 1982-2012, the channel-forming discharge was calculated as $\mathrm{Q}_{\text {ch-form. }}=72 \mathrm{~m}^{3} / \mathrm{s}$ and it lasted with higher for 172 days. The maximum observed discharge was $\mathrm{Q}_{\max }=385 \mathrm{~m}^{3} / \mathrm{s}$.

The aerial pictures taken in 2012 and 2015, show that the river training works of 1982 successfully stabilized the river channel. At $\mathrm{km}$ $83+400$ of the river course, just behind the new bridge construction the channel is divided into two different parts. It is caused by the pier of the bridge located it the middle of the main channel.

Prognosis: After the last river training works, taken in 1982, the conditions of the channel are 
stable. It is well-seen on the aerial photo taken in 2015. Therefore, the hydraulic parameters of the channel (longitudinal slope, $\omega, \tau$ ) will reach a similar value to that of the state before the works of 1967 - the riverbed will still be stable. Model tests are required to confirm this.

Section-4 is a junction of the main Raba river channel and both-sides its two tributaries. On the basis of the aerial photographs taken in 1963, it can be seen that the channel was braided with bed-forms and bars, and with bed activity ranged to $200 \mathrm{~m}$. The visible up-stream sinusoity of both tributaries mouth, the right-sided sinusoity of the right-side tributary, becomes one of the reasons for the instability of the right bank in Section-3 located above.

In years 1963-1967, the channel-forming discharge was calculated as $\mathrm{Q}_{67 \%}=102 \mathrm{~m}^{3} / \mathrm{s}$ and it lasted with higher for 5 days only. The maximum observed discharge was $\mathrm{Q}_{\max }=257 \mathrm{~m}^{3} / \mathrm{s}$.

In 1967, the channel was narrowed due to the project up to the width of $30 \mathrm{~m}$ with both-sides limited by groyneses (Project 1967). The current field observation and the aerial photos show that the channel still tends to widen gradually. In the years 1967-1980, the channel-forming discharge was calculated as $\mathrm{Q}_{\text {ch-form }}=58 \mathrm{~m}^{3} / \mathrm{s}$ and it lasted with higher for 52 days. The maximum observed discharge was $\mathrm{Q}_{\max }=475 \mathrm{~m}^{3} / \mathrm{s}$.

In the 1980 s aerial photo, it can be seen that the training works of 1967 led to balancing the river channel processes throughout the entire section. The exception is the area with the mouth of the right-side tributary where the process of sedimnt deposition was observed. In the years 1980-2012, the channel-forming discharge was calculated as $Q_{\text {ch-form }}=72 \mathrm{~m}^{3} / \mathrm{s}$ and it lasted with higher for 199 days. The maximum observed discharge was $\mathrm{Q}_{\max }=385 \mathrm{~m}^{3} / \mathrm{s}$.

The aerial photo of 2015 shows that the newly formed channel took over the function of the main river channel, connecting with the mouth of the left-side tributary. Total destruction of the left bank revetment is observed. The old river channel (at the right bank) is gradually covered with the sediments. The lower course of the channel in Section-4 is stabilized In years 2012-2015 the channel-forming discharge was calculated as $\mathrm{Q}_{\mathrm{ch}}$ form. $=76 \mathrm{~m}^{3} / \mathrm{s}$ and it lasted with higher for 6 days only. The maximum observed discharge was $\mathrm{Q}_{\max }=361 \mathrm{~m}^{3} / \mathrm{s}$.

Prognosis: The destruction of left bank revetment was probably caused by excessive narrowing of the channel in 1967 (30 m). Currently, without the stabilization of the left-side tributary's mouth, the processes of channel moving towards the Kraków-Zakopane national road will continue. The right bank of the channel could be stable. However, the determination of hydraulic parameters will indicate the intensity of the course of channel moving.

The calculated specific stream power $\omega$ ranges from 33 to $38 \mathrm{~W} / \mathrm{m}^{2}$ in the regulated channel (Section-1 - Section-3), whereas in the natural channel (Section-1 - Section-3) of the studied sections it ranges $12-14 \mathrm{~W} / \mathrm{m}^{2}$. The patterns of change in $\omega$ are highly correlated to the changes in channel slope and width due to projects executions. In most cases, as other authors observed (Bledsoe et al., 2002; Brookes, 1987), the channel changes have often been associated with specific stream power value. It can be considered as an indicator of zones of potential sediment movement throughout the river reach. High changes of stream power can be generally associated to erosion (increase of $\omega$ ) or sediment accumulation (decrease of $\omega$ ), (Reinfelds et al., 2004, Radecki-Pawlik 2002) as it is observed in four studied currently sections. Shear stress $(\tau)$ were examined as well in order to confirm the sediment movement ability.

\section{CONCLUSIONS}

1. The history and evolution of the selected part of the Raba river was assessed using all the available data, from various sources.

2 . The data was analyzed concerning the vertical and horizontal evolution of river bed.

3. Unfavorable changes of the river bed (concerning existing development of the river valley) on some areas were stopped (Section-3) meaning that intervention was successful. On some of them (Section-2 and Section-4), it is deteriorating.

4. One of the main causes of growing instability of the river bed, as determined by the research, was too narrow channel width, which was the result of river training works.

5. Provisional prognosis of future changes was formulated based on available data and its analysis. However, much more detailed research, including water flow and bed-load modeling is needed.

6. As research progressed, a string of technical issues were found, mostly concerning the 
use of incoherent historical data for integrated river bed evolution analysis. The first step was therefore to bring about the data to the state useful for further work. It affected aerial photos and maps, historical construction projects and other data, including river hydrology.

7. Data acquired and distributed at the present time, using current technology shall be free of these issues, as a basis for a new standard in the river bed analysis. That is:

a) Making aerial photographs during, or just after major flood events.

b) Prompt calibration and orthogolisation of that aerial photos.

c) Historic and traditional way of marking of positions of structures along river using kilometer marks shall be abolished, as it leads to uncertainties and errors concerning the actual position of structures. Any geographic coordinate system deemed to be useful and convenient can be used instead (for example Polish PL2000, international WGS84 or other).

d) Detailed measurements of the river bed geometry and granulometric composition, including its submerged part, shall be done in regular intervals, especially after main flood events.

e) Only an integrated analysis, taking into consideration maximum available data (including all aerial photos and maps, all known river training projects) must be used to formulate prognosis of river channel evolution.

\section{REFERENCES}

1. Ashmore P. 2001. Braiding phenomena: statics and kinetics. In Gravelbed Rivers V, Mosley MP (ed.). New Zealand Hydrological Society: Wellington; 95-121.

2. Bagnold, R.A., 1980. An empirical correlation of bedload transport rates in flumes and natural rivers. Proc. R. Soc. Lond. A 372 (1751), 453-473.

3. Bertoldi W, Zanoni L, Tubino M. 2009. Planform dynamics of braided streams. Earth Surface Processes and Landforms 34: 547-557.

4. Bledsoe, B.P., Watson, C.C., Biedenham, D.S., 2002. Quantification of incised channel evolution and equilibrium. J. Am. Water Resour. Assoc. 38, 861-870.

5. Brasington J, Langham J, Rumsby BT. 2003. Methodological sensitivity of morphometric estimates of coarse fluvial sediment transport. Geomorphology 53: 299-316.
6. Brasington J, Rumsby BT, Mcvey RA. 2000. Monitoring and modeling morphological change in a braided gravel - bed river using high resolution GPS - based survey. Earth Surface Processes and Landforms 25: 973-990.

7. Bravard, J.-P., Kondolf, G.M., Piegay, H., 1999. Environmental and societal effects of channel incision and remedial strategies. Incised River Channels: Processes, Forms, Engineering and Management. Wiley, pp. 303-341.

8. Brookes, A., 1987. River channel adjustments downstream from channelization works in England and Wales. Earth Surf. Process. Landf. 12, 337-351.

9. Carbonneau PE, Lane SN, Bergeron NE. 2004. Catchment-scale mapping of surface grain size in gravel bed rivers using airborne digital imagery. Water Resources Research.

10. Egozi R, Ashmore P. 2009. Experimental analysis of braided channel response to increased discharge. Journal of Geophysical Research -Earth Surface 114: F02012.

11. Ferguson R, Ashmore P, Ashworth P, Paola C, Prestegaard K. 1992. Measurements in a braided river chute and lobe. I: Flow pattern, sediment transport and channel change. Water Resources Research 8: 1877-1886.

12. Gomez B. 1991. Bedload transport. Earth Science Reviews 31: 89-132.

13. Lane SN, Chandler JH, Richards KS. 1994. Developments in monitoring and terrain modelling of small - scale river bed topography. Earth Surface Processes and Landforms 19: 349-368.

14. Legleiter C.J. 2013, Mapping river depth from publicly available aerial images, River Res. Applic. 29: 760-780.

15. Lisle, T.E. 2005. Bed mobility: A key linkage between channel condition and lotic ecosystems. Eos, Transactions of the American Geophysical Union 86: Joint Assembly Supplement, Abstract B44B-01.

16. May, C.L., Pryor, B., Lisle, T.E., and Lang, M. 2009. Coupling hydrodynamic modeling and empirical measures of bed mobility to predict the risk of scour and fill of salmon redds in a large regulated river. Water Resources Research 45: W05402.

17. Meyer-Peter, E. and Müller, R., 1948. Formulas for bed-load transport, Report on second meeting of IARH. IAHR, Stockholm, Sweden, pp. 39-64.

18. Mosley, M. P. (1982), Analysis of the effect of changing discharge on channel morphology and instream uses in a braided river, Ohau River, New Zealand, Water Resour. Res., 18, 800-812.

19. Nelson, P.A., Venditti, J.G., Dietrich, W.E. et al. 2009. Response of bed surface patchiness to reductions in sediment supply. Journal of Geophysical Research-Earth Surface 114: F02005. 
20. Parker, C., Clifford, N.I., Thorne, C.R., 2011. Understanding the influence of slope on the threshold of coarse grain motion: revisiting critical stream power. Geomorphology 126, 51-65.

21. Peirce S., Ashmore P., Ledux P. 2018. The variability in the morphological active width: Results from physical models of gravel-bed braided rivers, Earth Surf. Process. Landforms 43, 2371-2383.

22. Radecki-Pawlik A., 2002. Bankfull discharge in mountain streams: theory and practice. Earth Surface Processes and Landforms. Vol. 27. Iss. 2 p. 115-123.

23. Reinfelds, I., Cohen, T., Batten, T., Brierley, G., 2004. Assessment of downstream trends in channel gradient, total and specific stream power: a GIS approach. Geomorphology 60, 403-416.

24. Rumsby BT, Brasington J, Langham JA, McLelland SJ, Middleton R, Rollinson G. 2008. Monitoring and modelling particle and reach scale morphological change in gravel - bed rivers: applications and challenges. Geomorphology 93: 40-54.

25. Stevens, M.A., Simons, D.B. and Richardson, E.V. 1975. Nonequilibrium river form. American Society of Civil Engineers, Journal of the Hydraulics Division 101: 557-566.
Technical Projects:

26. Projekt regulacji rzeki Raby od $\mathrm{km} 84+300$ $78+514$ m. Pcim - Stróża, Projekt techniczny: TD235/67, Okręgowy Zarząd Wodny Krakowie, (Egz. Arch - Państwowe Gospodarstwo Wody Polskie RZGW - Kraków). (in Polish).

27. Umocnienie brzegów koryta od km $81+250$ $82+150$, Projekt techniczny: ID-225/203/73, Przedsiębiorstwo Budownictwa Wodnego w Krakowie, Pracownia Projektowa, (Egz. Arch Państwowe Gospodarstwo Wody Polskie - RZGW - Kraków). (in Polish).

28. Regulacja rzeki Raby w km 78+240 - 80+200, Projekt techniczny: UP2/76, Przedsiębiorstwo Budownictwa Wodnego w Krakowie, Pracownia Projektowa, (Egz. Arch - Państwowe Gospodarstwo Wody Polskie - RZGW - Kraków). (in Polish).

29. Rzeka Raba odkm83+300-84+200w miejscowości Pcim, Projekt techniczny: OK.-1226/P/82, Hydroprojekt - Kraków, Egz. Arch - Państwowe Gospodarstwo Wody Polskie - RZGW - Kraków). (in Polish).

30. Projekt techniczny regulacji rzeki Raby w km 81+8840 - 80+900, Kraków 1987, (Egz. Arch Państwowe Gospodarstwo Wody Polskie - RZGW - Kraków). (in Polish). 